\title{
The Effect of Charter Schools on Districts' Student Composition, Costs, and Efficiency: The Case of New York State
}

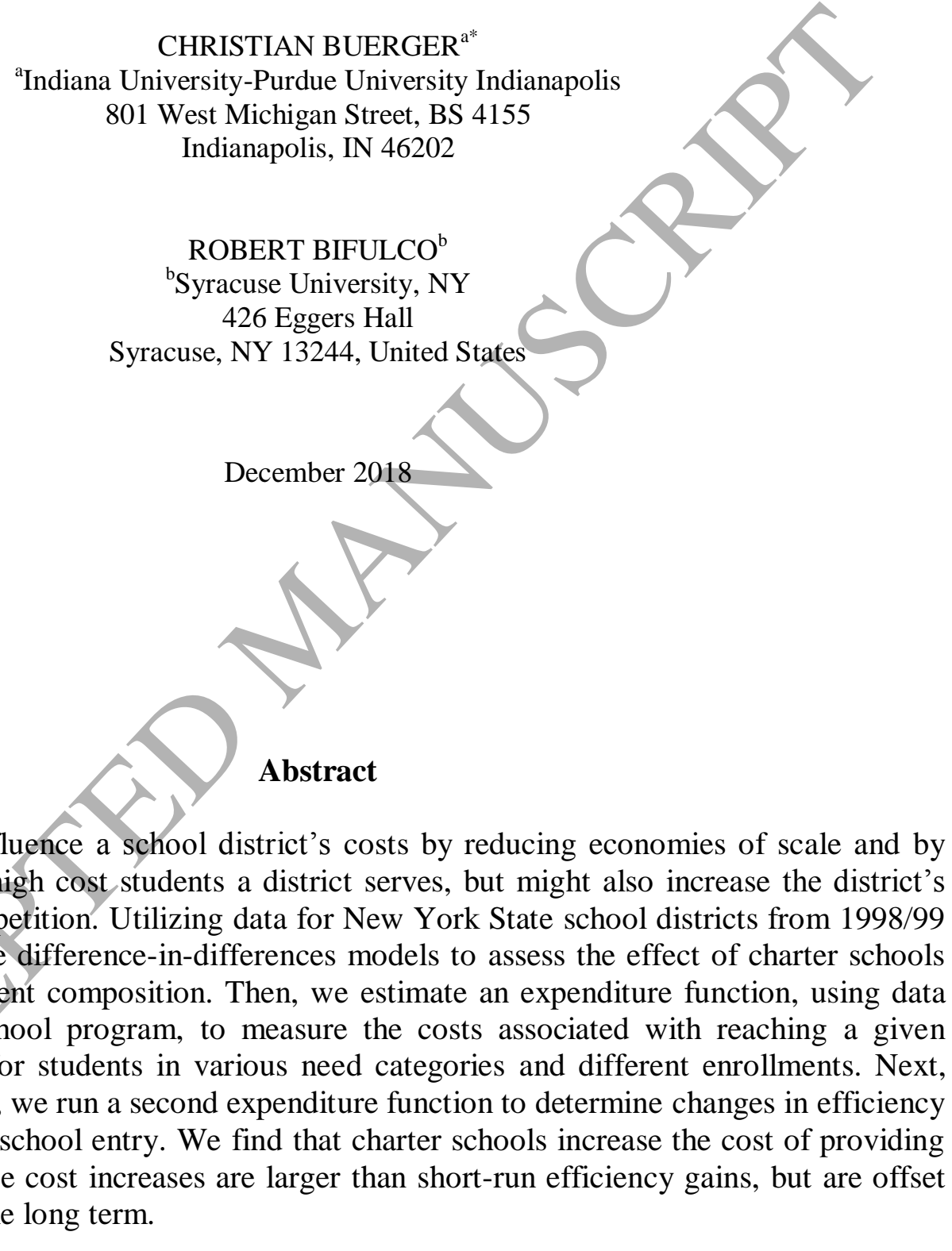

Charter schools can influence a school district's costs by reducing economies of scale and by changing the share of high cost students a district serves, but might also increase the district's efficiency through competition. Utilizing data for New York State school districts from 1998/99 to 2013/14, we estimate difference-in-differences models to assess the effect of charter schools on enrollment and student composition. Then, we estimate an expenditure function, using data prior to the charter school program, to measure the costs associated with reaching a given performance standard for students in various need categories and different enrollments. Next, using the entire data set, we run a second expenditure function to determine changes in efficiency associated with charter school entry. We find that charter schools increase the cost of providing education, and that these cost increases are larger than short-run efficiency gains, but are offset by efficiency gains in the long term.

Keywords: costs, efficiency, expenditures, school choice JEL: I21, I22, H75

\footnotetext{
* Corresponding author: +1 (317) 274-4177; cbuerge@iupui.edu
} 


\section{Highlights}

- Charter schools change the costs and efficiency of providing education in school districts.

- Cost increases are driven by increases in share of poor students in traditional public schools.

- Charter school increase the efficiency of providing education. The effects are larger in the long than in the short-run.

- The cost increases are larger in the short-run than the efficiency gains, but in the long run efficiency gains offset cost increases. 


\section{Introduction}

Since the beginning of the charter school movement, concerns have been raised that charter schools would drain resources from traditional public schools and increase per pupil costs by attracting students that are the least costly to educate (Arsen, Plank, \& Sykes, 1999; Molnar, 1996; Moody's, 2013). On the other hand, advocates have argued that competition created by charter schools can be "a tide that lifts all boats" by pushing public schools to increase efficiency (Hoxby, 2003b). Given the financial constraints many school districts faced after the Great Recession (Hull, 2010; Jackson, Wigger, \& Xiong, 2018) and the growing number of charter schools (NCES, 2018), the question of how charter schools influence districts' student composition, costs, and efficiency is more salient than eyér.

A few studies have examined the impact of charter schools on district revenues and expenditures finding negative fiscal impacts, i.e. that the loss in revenues due to charter schools are greater than expenditure reductions made possible by transfer of students to charter schools (Arsen \& Ni, 2012; Bifulco \& Reback, 2014; Ladd \& Singleton, 2018). Charter school programs typically transfer revenues close to average spending per pupil from traditional public schools to charter schools. However, a substantial proportion of a districts costs are fixed over some shortterm, and thus, the amount of spending the district can shed when a student transfers to a charter school is less than average spending per pupil. Note that this argument is one about short-run fiscal impacts. From a long-run perspective, a much lower proportion of a district's costs are fixed and so the amount of spending a district can shed in response to a charter school enrollment should be much closer to average per pupil spending and the amount of revenue transferred to charter schools. 
Nonetheless, charter schools can have longer run fiscal impacts on traditional public school districts for at least two reasons. First, the transfer of students out of traditional school to charter schools can shift the cost function faced by a local school district. That is, charter school enrollments can increase the per pupil expenditures required by a district using standard technologies and practices to achieve targeted student outcomes. A significant literature shows that the per pupil expenditures required to achieve targeted student outcomes, i.e. district costs, are influenced by the number of student served and the additional needs students may have (Downes, 2004; Downes, \& Stiefel, 2008; Downes \& Pogue, 1994; Duncombe \& Yinger, 1998, 2005, 2008, 20011a, 2011b; Eom, Duncombe, Nguyen-Hoang, \& Yinger, 2014; Imazeki, 2008; Imazeki \& Reschovsky, 2003, 2004, 2006; Reschovsky \& Imazeki, 2001 2003). In particular, larger school districts might be able to achieve economies of scale and thus require lower per pupil expenditures to achieve a given level of outcomes. Thus, when a traditional public school district loses students to a charter school the district may suffer diseconomies that increase the per pupil costs of achieving educational outcomes. Also, students from low-income families, English language learners, and/or students with disabilities will tend to have additional needs, and thus require more resources to achieve educational outcomes. So if transfers to charter school change the proportion of students served by a district who are in these high need categories, then that can also shift the cost function faced by a school district.

Several studies have tried to estimate the effect of charter schools on student composition in traditional schools. Regarding the enrollment of low-income students, the evidence is mixed, with several studies finding that charter school have higher concentrations of nearby poor students than traditional public schools (Abdulkadiroglu, Angrist, Cohodes, Dynarski, Fullerton, Kane, \& Pathak, 2009; Carnoy, Jacobsen, Mishel, \& Rothstein, 2005; Epple, Romano, \& 
Zimmer, 2016; Sass, 2006) and others finding lower concentrations of poor students in charter schools compared to nearby traditional public schools (Booker, Gilpatric, Gronberg, \& Jansen, 2008; Finnigan, Adelman, Anderson, Cotton, Donelly, \& Price, 2004; Hoxby, Murarka, \& Kang, 2009; Tuttle, Teh, Nichols-Barrer, Gill, \& Gleason, 2010). Most researchers agree that charter schools serve fewer special education students and English language learners than nearby traditional public schools (Abdulkadiroglu et al., 2009; Bifulco \& Buerger, 2015; Finnigan et al., 2004; Miron, Urschel, Mathis, \& Tornquist, 2010; Sass 2006). As some charter schools specialize in educating these student groups, however, there is a large variation in what students are drawn to charter schools (Thernstrom \& Thernstrom, 2003). None of these studies have tried to quantify the effect of enrollment changes that result from charter schools on district costs.

The second way that charter schools can affect district expenditures, and thus their fiscal position, in the long-run is by influencing district efficiency. Thus, if competition for students and revenues spur school districts to use resources more efficiently to achieve student outcomes, then the per pupil expenditures a districts actual spends to achieve a given level of student outcomes will decrease. Several studies have tried to estimate the effect of charter schools on the performance of students who remain in traditional public schools (Booker et al., 2008; Bettinger, 2005; Cordes, 2017; Imberman, 2011; Zimmer, Gill, Booker, Lavertu, \& Sass, 2009). Only a few researchers have found positive effects and most studies have found no effect at all. ${ }^{2}$ However, because these studies do not simultaneously examine the effects of charter schools on district expenditures, they do not tell us the effect of charter schools on school district efficiency. Among the studies of which we are aware of, one has tried to estimate the efficiency of charter school relative to traditional public schools (Gronberg, Jansen, \& Taylor, 2012), but none have tried estimate the effect of charter schools on the efficiency of traditional public schools.

\footnotetext{
${ }^{2}$ For a comprehensive overview of the literature see Gill (2016) and Epple et al. (2016).
} 
This study draws on concepts from the literature on educational costs to estimate the effect that charter schools have on the amount of per pupil expenditures districts spend to achieve a given level of student outcomes, i.e. on district costs and efficiency. More specifically, we investigate the following three research questions: 1) what is the impact of charter schools on student composition and enrollment in traditional public schools; 2) what is the effect of changes in student composition and enrollment caused by charter schools on district costs; and 3) how does charter school competition affect school district efficiency.

Our empirical strategy builds on techniques applied in program evaluation (Card \& Krueger, 1994; Angrist \& Pischke, 2009) and education cost-funetion research (Downes, 2004; Downes, \& Stiefel, 2008; Downes \& Pogue, 1994; Duncombe \& Yinger, 1998, 2005, 2008, 20011a, 2011b; Eom, Duncombe, Nguyen-Hoang, \& Yinger, 2014; Imazeki, 2008; Imazeki \& Reschovsky, 2003, 2004, 2006; Reschovsky \& Imazeki, 2001 2003). Utilizing data from New York State, we start by using difference-in-differences models to estimate the effect of charter school entry on district enrollment and the percentages of students in various need categories. Next, we estimate an expenditure function using information for the 1998/99 school year, the only year in our data set without charter schools, controlling for service outcomes, factors related to district costs, and other factors that might influence district efficiency. The results of this expenditure function provide us with cost measures for students in various need categories and enrollment. Additionally, we estimate a second expenditure function utilizing all years in our data set, including only previously defined treatment and control districts, and adding districts and year fixed effects to measure the impact of charter schools on school district efficiency. In a final step, using estimates from the difference-in-differences models and the first expenditure 
function, we calculate changes in district costs associated with charter school entry and compare them with the charter school efficiency effects from the second expenditure function.

Our findings are consistent with research showing that charter schools increase the proportion of students in traditional public schools who come from low-income families and who have disabilities. We also find that the entry of charter schools is associated with a decrease in the proportion of students who have limited English proficiency in traditional public schools. However, only the changes in students receiving free lunch caused by charter schools are large enough to have a statistically significant impact on per pupil costs. Overall, charter schools increase the minimum per pupil amount a typical sized district needs to spend for a given level of performance by 7.5 percent in the short-run and by 7.1 percent in the long-term.

Our results also suggest that efficiency gains in response to charter school entry decrease the per pupil amount districts spend to achieve a given level of outcomes by 3.6 in the short-term and 6.8 percent in the longer-run. This finding is consistent with literature showing that charter school entry leads to improved service provision in traditional public schools. Comparing cost increases and efficiency gains, charter schools increase traditional public schools' expenditure per pupil used to reach a given performance level by 3.9 percent in the first four years and by 0.25 percent five and more years after charter school entry. Thus, on average, charter schools increase costs in the short-term but increases in efficiency offset these cost increases in the long run.

We further find that school districts with high levels of charter schools enrollments, relative to districts with small charter school enrollments, experience smaller increases in costs and larger efficiency gains leading to net reductions in the expenditures used to achieve a given 
level of outcomes of 4.6 percent in the first four years after charter school entry and 11.6 percent in later years.

Our findings contribute to the existing literature in the following ways. First, we provide additional evidence that charter schools impact enrollment and student composition in traditional public schools. Second, our study establishes, theoretically and empirically, that charter school programs can influence the cost and efficiency of traditional public schools districts, and that both of these factors have to be considered in estimating the net effect of charter schools on spending in traditional public schools. Third, we develop an approach that combines methods from program evaluation and cost function literature to estimate the effects of charter schools on school district expenditures - clarifying both the strengths and limitations of the approach. Finally, we provide evidence that the entry of charter schools in New York has both increased both per pupil cost of education and efficiency in traditional public school districts.

The remainder of the article is organized as follows. Section 2 describes the charter school program in New York State. Sections 3 and 4 lay out the key conceptual considerations that guide the interpretation of the analysis and outline the empirical strategy. Section 5 describes the samples and measures we use to implement our empirical strategy. Section 6 presents the results of our analysis and Section 7 investigates if districts with large charter school enrollments experience charter school effects that are different from the average district. The last section summarizes our conclusions.

\section{New York State Charter School Program}

In New York State, the first charter schools began operating in the fall of 1999. Students are able to apply for admission and schools selects students by lottery if they are oversubscribed. Although students outside the district where a charter school is located can be admitted, the 
lottery process gives preference to students residing in the district in which the charter school is located (NYS Charter School Law Subsection 2854 (2b)).

A charter school's primary source of funding in New York State is per pupil payments from the districts in which their students reside. The amount a district pays per student is equal to the approved operating expenses per pupil in the district. Also, charter schools receive additional funding for students with disabilities from the district. The additional weight students with disabilities receive in the funding formula varies between 1.65 for students with severe disabilities and 0.9 for students with less severe disabilities. Charter schools do not receive additional funding for students with limited English proficiency or those living in poverty. Further, the districts provide textbooks, software, transportation, health and special education evaluation services to charter schools (NYS Charter School Law Subsection 2853).

Charter schools in New York are closely regulated by the charter school authorizers, which include the SUNY Board of Trustees and the State Board of Regents. Additionally, local school district boards are able to approve district schools converting to charter schools, with final approval given by the State Board of Regents. The National Alliance of Public Charter Schools identifies New York as being among the top states in the use of comprehensive monitoring and data collection as well as clear renewal, nonrenewal, and revocation processes to oversee charter schools (NAPCS, 2017).

For data availability reasons, we focus on charter schools outside New York City (NYC) in this study. Table 1 shows the 20 districts outside NYC that have or have had charter schools since 1999/00. The first charter school was opened in Albany in the fall of 1999. The highest counts of charter schools are in Albany, Buffalo, and Rochester. Albany, Buffalo, and 
Lackawanna have the highest shares of charter school enrollments with more than 20 percent of resident public school students attending charter schools in these districts.

For the purpose of defining which districts are exposed to charter school competition, it is worth noting that all of the districts that have substantial charter school enrollments (more than 3 percent) also have high shares of low-income students (more than 39 percent being eligible for free lunch). In contrast, even when charter schools locate in districts with low levels of poverty, only small numbers of students from these districts choose to attend charter schools. For a handful of charter schools, including those located in Greece, Ithaca, Kenmore-Tonawanda, and Roosevelt, the majority of their enrollments are drawn from outside the district where they are located. With the exception of Roosevelt, the districts where these charter schools are located have low levels of charter school enrollment themselves and low levels of poverty, while the adjacent districts that send the majority of students to the charter school have high shares of charter school enrollment and high percentages of students receiving free lunch. So it appears that districts with relatively high percentages of low-income students (above 39\%) and that have charter schools located within their boundaries or in an adjacent school district are subject to charter school competition.

Table 2 breaks down charter school enrollment for different grade levels and years. In all but six districts, charter schools start with enrolling students in grades $\mathrm{K}$ to 8 and nine districts add additional grade levels in later time periods while two districts serve only high school students. Thus, charter schools tend to use entry strategies that start with small enrollments in early grades and then increase student numbers and grade levels over time. 


\section{Conceptual Considerations}

Analysis can focus on the impacts of charter schools on the public school system as a whole, including charter and traditional public schools, or on the traditional public schools themselves. Estimates of impacts on the entire system of public schools and thus, all public school students, would provide a more comprehensive picture. However, much of the discussion of charter schools has focused on the impacts on traditional public schools, including the questions of whether or not charter schools drain resources, cream-skim low cost students, or push traditional public schools to operate more efficiently. For this study, reliable fiscal data on charter schools is not available in a form that is comparable to that available for traditional public school districts, and so we focus on the effects of charter schools on traditional public schools.

We use a cost function approach to characterize the relationship between spending, student performance, and other school district characteristics. Costs are defined as the minimum spending required to reach a given level of student performance using current best practices. Because not all districts operate efficiently and we cannot directly observe which districts are and are not efficient, costs cannot be observed directly and cost functions have to be estimated using district spending as the dependent variable and indirect controls for efficiency. Spending is greater than costs when school districts are inefficient and deviate from current best practices (Downes \& Pogue, 1994; Duncombe \& Yinger, 1998, 2005, 2008, 2011a, 2011b; Reschovsky \& Imazeki, 2001, 2003).

More formally, education costs, $C$, are determined by student performance, $S$, resource prices $W$, student composition $P$, and enrollment, $N$. If we let $e$ stand for school district efficiency with a value of 1 in an efficient school district and a value between zero and one for an inefficient district, then the expenditure function can be written as: 
Charter schools can influence a district's costs in at least two ways. First, if there are economies of scale in education, then sufficiently large reductions in district enrollments due to students transferring to charter schools will increase the amount of per pupil expenditure required to achieve a given level of service outcomes. Second, charter schools ean change the composition of students remaining in district schools (Abdulkadiroglu et al., 2009; Finnigan et al., 2004; Epple et. all, 2016). For instance, some studies have found that students from lowincome families, with limited English proficiency (LEP), and/or disabilities are less likely to transfer to charter schools than other students (Jabbar, 2016; West, Ingram, \& Hind, 2006). If so, then charter school entry will increase the proportion of students in district schools with high levels of educational need, and thus, will increase the costs of achieving a given level of student outcomes.

Charter schools may also influence the efficiency with which a school district operates. Advocates of expanding public school choice have argued that forcing public schools to compete for students will provide incentives for districts to improve services (Hoxby 2000, 2003a, 2003b). If districts respond to charter school competition by adopting new educational programs or by reallocating resources from less to more productive uses, this could increase district efficiency. There are also reasons to believe that charter school competition might reduce the efficiency with/which districts operate. First, Rockoff (2010) and Duncombe and Yinger (2011a, 2011 b) argue that it takes time for districts to adjust to rapid, unforeseen changes in enrollment, and thus, in the short-run, charter schools might reduce district efficiency. For instance, unforeseen reductions in enrollment might result in underutilization of administrators, facilities, or teachers in certain subjects (Bifulco \& Reback, 2014). Second, the district might respond to 
the entry of charter schools by adopting new programming that requires additional expenditures. If these new programs fail to increase student outcomes, then the result will be decreased efficiency.

\section{Empirical Strategy}

Our empirical strategy starts with determining treatment and control districts. Then, we utilize difference-in-differences models to estimate the effect of charter school entry on district enrollment and the percentages of students in various need categories. Next, we estimate an expenditure function using information for the 1998/99 school year, the only year in our data set without charter schools. The results of this expenditure function proyide us with cost estimates for students in various need categories and enrollment. Additionally, we estimate a second expenditure function using all years in our data set and the treatment and control districts established in the first step of the empirical strategy. We include in this equation a charter school identifier to measure how charter schools influence school district efficiency. Finally, using estimates from the first expenditure function and the difference-in-differences models, we calculate changes in district costs and compare them with the charter school efficiency effects from the second expenditure function.

Table 1 shows that all districts with a high share of charter school enrollment are located in or adjacent to a district that has a charter school. There are no districts with low-shares of free lunch eligible students in 1999/00 that ever reach significant levels of charter school enrollment during the time period we observe, even when charter schools are located within the district borders or close by. Because having charter schools located nearby and having a high share of students in poverty are the primary predictors of charter school enrollment, we define our treatment group as all school districts that have charter schools or that are adjacent to a district 
with a charter school and that have at least 39 percent of students receiving free lunch during the 1999/00 school year. ${ }^{3}$ As a control group, we use all school districts with at least 39 percent share of students receiving free lunch in 1999/00 that neither have a charter within its border nor are adjacent to a district with charter school. Further, we limit the group of control districts to those that have an enrollment greater than 2,000 students because the treated districts are all at least that large. The final sample includes 14 control and 14 treated districts, each of which we observe for the year 1998-99 through 2013-14 (16 years). Of the 14 treated districts, 13 are observed for at least 8 post-treatment years. ${ }^{4}$

We begin the analysis by using this sample of treatment and control districts to estimate the effects of charter schools on the key factors related to costs that are likely to be influenced by charter school entry, namely enrollment and student composition. Specifically, we estimate:

where $Y_{d t}$ is either log of enrollment, percentage of free-lunch eligible, percentage of limited English proficient, or percentage of students with disabilities for district $d$ in year $t$; TREAT $d t$ is an indicator variable that takes the value of one for treatment group districts in the years after a charter school was first established in the district or an adjacent district, and 0 otherwise; $\delta_{d}$ is a district specific fixed effect, and $\theta_{t}$ represents year fixed effects. The district fixed effects control for district characteristics that do not change over time and the year fixed effects for annual shocks experienced by all districts in our sample. ${ }^{5}$ Estimates of $\alpha_{1}$ indicate how much more the variable of interest increased or decreased in the treatment districts during the years following

\footnotetext{
${ }^{3}$ In two districts, Utica and Greece, charter schools open in 2013/14. Because we do not observe a time period after the charter schools openings, we consider these areas control districts.

${ }^{4}$ The treatment districts include all of the districts listed in Table 1 that have 39 percent or more students receiving free lunch in 1999, plus Cohoes, Niagara Falls, and Rensselaer. As noted earlier, Utica and Greece are excluded from the treatment group and considered controls as we do not observe any impacts post-period.

${ }^{5}$ We also run models using district specific time trends. Compared to models without trends, the coefficients on the charter school variable are of similar magnitude but less precisely estimated.
} 
the entry of charter schools compared to control districts during the same years. The equations are estimated using OLS with robust standards errors clustered by district.

To estimate the effect of changes in enrollment and student composition on costs, we draw on the cost function literature (Downes \& Pogue 1994; Duncombe \& Yinger 1998, 2005, 2008, 2011a, 2011b; Eom, Duncombe, Nguyen-Hoang, \& Yinger, 2014; Reschovsky \& Imazeki 2001, 2003). Particularly, we estimate the following expenditure function:

where all variables are defined as before, and $\boldsymbol{M}$ is a vector of variables that influences efficiency (discussed below) and $v_{d t}$ is an idiosyncratic error term. ${ }^{6}$ Similar to prior studies, we include a quadratic term for enrollment to model potential economies of scale (Andrews, Duncombe, \& Yinger, 2002).

Unlike the other analyses in this paper, which use district fixed effects to control for district factors that remain constant overtime and only districts in the treatment and control groups defined above, we estimate Equation (2) using cross sectional information for the 1989/99 school year and a sample that includes all districts in New York State outside of New York City that have an enrollment of at least 2000 students. It is difficult to estimate the effect of many cost factors on expenditures in panel data models that include district fixed effects because too much of the variation in these factors is differenced away by fixed effects estimators (Duncombe, Nguyen-Hoang, \& Yinger, 2015; Duncombe \& Yinger, 2011b). In addition, estimating equation (2) with only 28 school districts results in imprecise parameter estimates. We choose to estimate the model using data from 1998-99 because it is the only school year in

\footnotetext{
${ }^{6}$ We state vectors and their coefficients in bold letters.
} 
our data without charter schools, and hence cost estimates cannot be influenced by charter enrollment.

School district spending and performance are simultaneously determined by district decision makers. Therefore, similar to Eom et al. (2014), we instrument for performance in our estimate of Equation (2) with exogenous traits of school districts in the rest of the district's county. A district's own choices are likely to be influenced by choices of nearby districts, and the choices of nearby districts are influenced by their exogenous traits. More specifically, we use average percentage of LEP students in the rest of the county as instruments.

The estimates of $\boldsymbol{\beta}_{\mathbf{3}}$ and $\beta_{4}$ together with $\beta_{5}$ in Equation 2 are interpreted as changes in district costs associated with alterations in student/composition and student enrollment, respectively. These estimates can be combined with the estimated effects of charter school entry on student composition and enrollment (from Equation 1) to calculate the change in district costs associated with charter school entry. Specifically, the changes in district costs are computed as:

$$
\ln (\bar{N})]
$$

where $\% \Delta \operatorname{cost} P_{x}$ is the percentage change in per pupil costs associated with a change in the percentage of students in a specific need category $P_{x} ; \bar{P}_{x}$ denotes the average percentage of students in need category, $x$,among the treated districts $\% \Delta \operatorname{cost} N$ is the percentage change in costs associated with a change in the enrollments; and $\bar{N}$ is average enrollment for treated districts prior to charter school enrollment. The coefficients $\alpha_{1 P_{x}}$ and $\alpha_{1 N}$ are the coefficients attached to the treatment variable in Equation 1 using percentages of students in various categories and the log of enrollment as dependent variables, respectively. For the estimated percentage change in district costs associated with charter induced changes in each cost variable, 
we estimate confidence intervals using linear combinations of the regression coefficients and their standard errors in Equation 3 and 4, which are based on the delta method. ${ }^{7}$ The total change in district costs is computed by adding up the change in costs associated with charter-induced changes in the percentages of low-income, disabled, and LEP students as well as enrollment.

We estimate a second expenditure function, using all years in our data set and the sample limited to the treatment and control districts described earlier:

where all variables are defined as before, and $\mu_{d}$ and $\eta_{t}$ are district and year fixed effects, respectively, and $\tau_{d t}$ is an idiosyncratic error term. As in our estimate of Equation 2, we instrument for performance with the average percent of LEP students in the county (excluding the focal district).

The coefficient on the treatment variable in Equation 5, $\gamma_{1}$, is our parameter of interest, and it captures the shift in the amount of expenditures used to achieve a given level of service outcome. Since this model controls for other factors that influence district costs, we interpret this coefficient as the effect of charter schools on district efficiency. This interpretation depends on the assumption that we have controlled for all factors that influence district expenditures and that are correlated with the entry of charter schools. Three aspects of our analysis make this assumption plausible. First, the inclusion of district fixed effects controls for any unobserved factors that have constant effects on the costs or efficiency of a district overtime. Second, year fixed effects control for the effects of any temporal shocks that affect treatment and control group schools similarly. Third, we include controls for a range of time varying variables that

\footnotetext{
${ }^{7}$ The confidence intervals for linear combinations are based on the delta method (Oehlert, 1992; Rice, 1994) and implemented using STATA's suest and lncom commands.
} 
might influence district efficiency. In this analysis, we do not worry that the variation in cost factors is limited by the inclusion of fixed effects, because we do not need to give a substantive interpretation to coefficients other than $\gamma_{1}$ in equation 5 .

In the last step of our analysis, we add the change in expenditures per pupil computed using the results from Equation 3 and 4 and changes in efficiency from Equation 5 to calculate the net effect of charter schools on school districts spending. Again, we compute confidence intervals using the delta method.

There are several reasons to expect that the effects of charter schools on traditional public schools costs and efficiency will depend on the length of time since charter school entry. First, in response to enrollment losses, schools can shed some types of fixed costs in the longer run that they might be unable to shed in the shorter run. Thus, while the initial shock of enrollment losses might lead to decreases in efficiency in the short run as fixed inputs are under-utilitized, in the longer run this potential source of inefficiency can be mitigated by cutting costs that are fixed only in the short run. Second, it might take schools some time to adopt changes in operations in response to charter school competition and those changes might take some time to realize efficiency gains. Third, Table 2 shows that charter schools, in their first year of operation, enroll small numbers of students in early grades and over time increase the number of students and grade levels. Both larger enrollment losses and the fact that more schools and grade levels are facing competition might prompt more significant responses from schools and districts, and thus, larger efficiency gains. To estimate changes in the effects of charter school on costs and competition over time, we estimate Equations (1) and (5) breaking the post period down into 1-4 years and 5-8 years after charter school entry. ${ }^{8}$

\footnotetext{
${ }^{8}$ We do not report results for being exposed more than eight years because we cannot discern between impacts based on the length of the treatment period and the composition of the treated districts. An indicator for being
} 
Two caveats on our analysis are worth noting. First, in the framework we are using, inefficiency arises when a district uses resources less effectively than current technology allows, or when it spends money on outcomes other than the ones measured and included in our estimation of the expenditure equation. If charter schools cause districts to decrease (or increase) spending to achieve objectives other than the measures of student test scores that we include in our analysis, then that will be reflected as an increase (or decrease) in efficiency in our analysis. Second, if charter schools attract relatively high achieving students away from district schools (controlling for free-lunch eligibility, LEP status, and disability), such that districts are unable to achieve a given level of outcomes without increasing per pupil expenditures, then that will be interpreted as a decrease in district efficiency. Similarly, if charter schools attract relatively low achieving students, districts should be able to achieve a given level of outcomes with lower per pupil expenditure, which we would interpret here as an increase in efficiency. In other words, we cannot determine whether the change in efficiency associated with charter school entry, as we measure it, is the result of improved district programming and operations or changes in the underlying ability of its students. ${ }^{9}$

\section{Data and Measures}

To estimate the effect of charter schools on school district expenditures, we use a data set including New York State school districts for the years 1998/99 to 2013/14 assembled from a variety of sources. Similar to prior studies, New York City is excluded because we do not have data necessary to include it in estimates of the cost function (Eom et al 2014; Duncombe \&

exposed for more than 8 year, however, is included in the estimation but not reported or discussed. Another strategy would be to drop observations for districts having charter schools for more than 8 years. In these specifications, we lose about ten percent of our observations and while the magnitude of the results is similar to the baseline results we present, coefficients are less precisely estimated particularly for the expenditure functions.

${ }^{9}$ It is worth noting that this limitation in interpretation would apply even if charter school entry were randomly assigned to districts. 
Yinger 2005). This section explains the variables used in the analysis in more detail. All variables are measured for traditional public schools in a school district.

\section{Spending Measures}

To measure spending, we used the school district operating expenditure measure from the Fiscal Profile Reporting System (FPRS) maintained by the New York State Education Department (NYSED). As in other cost function research (Eom et al. 2014), we use an expenditure measure that includes spending for instruction, support services (including transportation ${ }^{10}$ ), and debt services (principal and interest). We excluded all tuition payments to charter schools from the measure.

\section{Performance Measures}

We use performance measures drawn from the New York State school district report cards. These measures are based on standardized tests examining student proficiency in mathematics and English Language Arts. Starting in 1998/99, this system was used consistently until the 2009/10 school year when NYSED made a change in the state testing program and the cut scores required for proficiency. We use a similar approach to Eom et al. (2014) to overcome this inconsistency. Specifically, we calculate adjusted proficiency rates based on cut scores before the change in proficiency levels assuming that the distribution of student test scores follows a normal distribution. ${ }^{11}$

\footnotetext{
${ }^{10}$ Cost function studies often exclude transportation as this type of spending is affected by factors such as sparsity of population as well as weather and road conditions, which are not likely to affect instructional spending (Duncombe and Yinger 2011a). In NYS school districts have to provide transportation for charter schools, and hence we leave transportation in the spending measure to fully capture the effect of charter schools on traditional school expenditures.

${ }^{11}$ Eom, et al. (2014) describe the approach in footnote 24 "To correct the proficiency rates for a change in the cut score, we assume the distribution of student scores in each district follows a normal distribution. We then approximate the cumulative standard normal with: $\mathrm{F}\{\mathrm{Z}\}=1 /[1+\exp \{-1.702 \mathrm{Z}\}]$, where $\mathrm{Z}=(\mathrm{X}-\mu) / \sigma, \mathrm{X}$ is the test score, and $\mu$ and $\sigma$ are its mean and standard deviation, respectively. The proficiency rate at any given $\mathrm{Z}$ is $(1-$ $\mathrm{F}\{\mathrm{Z}\}$ ). Because our data set includes $\mu$ for each test in each district, we can use this equation to solve for $\sigma$ using the
} 
We construct a performance index consisting of the equally weighted average percentage of students reaching proficiency levels in mathematics and English Language Arts in 4th and $8^{\text {th }}$ grade. Further, we include the percentage of students receiving a Regents Diploma by passing at least five Regents exams and the percentage of students not dropping out of high school. This procedure allows us to include performance information for high school grades while still only needing one instrument for performance (instrument procedures are discussed later). Also, this approach is similar to Eom et al. (2014) and allows us to compare our cost function results with their findings.

\section{Cost-Related Measures}

Researchers have long recognized that the cost/of education depends on many factors outside a school district's control. These factors include the wage environment, student enrollment, and concentration of disadvantaged students among the student population (see Duncombe \& Yinger, 2008 for an overview). To control for teacher salaries, we include the Comparable Wage Index (CWI) developed by Taylor and Fowler for the National Center for Education Statistics. The CWI is a measure of the systematic, regional variations in the salaries of college graduates who are not educators (Taylor \& Fowler, 2005). ${ }^{12}$ District enrollment counts are also drawn from NYSED Report Cards and represent official counts of students registered in the district as of October 1 of each school year. As in other work on cost functions, we use the $\log$ of student enrollment and the log of enrollment squared to allow for a nonlinear relationship between per pupil expenditures and enrollment (Duncombe \& Yinger, 2008, 2011a, 2011b). We also include the percent of students eligible for free or reduced price lunch, students with limited

observed new cut score, $\mathrm{X}_{\mathrm{NEW}}$, and the associated proficiency rate. With this estimate of $\sigma$ we can then calculate $\mathrm{Z}_{\mathrm{OLD}}=\left(\mathrm{X}_{\mathrm{OLD}}-\mu\right) / \sigma$, where $\mathrm{X}_{\mathrm{OLD}}$ is the old cut score. The proficiency rate at the old cut score is $\left(1-\mathrm{F}\left\{\mathrm{Z}_{\mathrm{OLD}}\right\}\right)$."

${ }^{12}$ Comparable wage index values estimated by Lori Taylor using the methods developed for NCES for each district and each year in our sample are available at http://bush.tamu.edu/research/faculty/Taylor_CWI/. 
English proficiency, and students with disability, all of which are drawn from the NYSED school district report cards.

\section{Efficiency-Related Measures}

Costs are defined as the minimum spending required to provide students an opportunity to reach a given level of student performance. However, the dependent variable in the cost model is actual per pupil spending and if a district operates inefficiently, actual per pupil spending will exceed the minimum required spending. While it is not possible to measure efficiency directly, it is possible to control for it indirectly and thereby to minimize any omitted variable bias.

Based on Duncombe and Yinger (2005, 2011a, 2011b), we control for efficiency by including variables in the expenditure function that have been linked to school district efficiency in previous research, but are themselves unlikely to be influenced by charter school entry. These efficiency-related variables include resident income, share of state aid, local tax share, percentage share of residents with college degrees, and the share of youth in the district. ${ }^{13}$

Taxpayers in districts with high resident income and high shares of state aid are less likely to pressure public officials to operate efficiently compared to districts with lower fiscal capacity. They could also be more apt to spend money on non-tested subjects. As our performance measurement only captures improvement in test scores, the additional spending for non-tested subjects could decrease school district efficiency. The local tax share is defined as the ratio between the median housing value and the average per pupil housing value in the district. The smaller the ratio, the less the median voter in the district has to pay for an additional unit of education. Therefore, smaller ratios potentially increase the demand for education, but are also

\footnotetext{
${ }^{13}$ Eom et al. (2014) use New York States School Tax Relief Program (STAR) as efficiency variable. As models with and without the STAR variable show the same results, we decided to exclude the STAR measure from our expenditure function.
} 
likely to decrease the incentive to monitor public officials. Demographic factors, such as the share of college educated parents and the share of children in the total population, have been found to decrease school district efficiency, and hence, we include these demographic factors in the cost models as well. The specific efficiency-related variables included in our analysis and the data sources used to construct those variables are detailed in Table 3.

Table 3 provides the summary statistics for the baseline year 1998/99, the only year in the data set without any charter schools. All variables are presented separately for treated and control districts. Differences in means are tested using a t-test. We see that the treatment and control districts are similar on the means of all variables, except that the treatment districts have significantly larger enrollments on average.

\section{Results}

\section{Impacts on Student Composition and Enrollment}

Table 4 provides the results for the difference-in-differences models measuring the impact of charter schools on cost-related factors. The table includes separate columns for each of the four dependent variables: percentage of the students eligible for free-lunch, percentage of students with limited English proficiency, percentage of students with disabilities, and the log of student enrollment in the district. The first column for each of the four dependent variables uses a single treatment variable which takes the value of one in all treatment districts in all years after the entry of the first nearby charter school. The second column splits up the post period and reports results for one to four and five to eight years after charter entry, allowing us to measure changes in the charter effect over time.

Estimates using a single post period for the entire time after charter school opening suggest that charter school entry on average is associated with an increase in the share of 
students receiving free lunch and the share of students with disabilities (i.e. who have an Individualized Education Plan - IEP), and a decrease in the share of students with limited English proficiency. The estimated effects indicate that after charter school entry, a district's share of students receiving free lunch increases by almost 3 percent, the percent of students with disabilities increases by 1.61 percent, and the share of students with limited English proficiency decrease by 2.8 percent. The estimated effect of charter schools on the percent of students with limited English proficient is statistically distinguishable from zero at the 5 percent level, while the estimated effects on the share of students with disabilities and receiving free lunch is statistically significant at the 10 percent level. Looking at the results of the second specification, there is no evidence that any of these effects differ with the length of time that districts have been exposed to charter school competition.

The estimates in column (7) indicate that charter school entry is associated with a decrease in enrollment of 7.4 percent, and that those effects are somewhat larger five to eight years after entry, then one to four years after entry. That effects on enrollment grow over time is consistent with the expansion in charter school enrollments following initial entry that is evident in Table 2.

\section{Estimated Effects on Costs}

Table 5 presents the results for Equation 2 using information on school districts with more than 2000 students and for the school year 1998/99. In the first stage of the spending analysis, which is used to address the endogeneity of student performance measures in the expenditure function, we use the average percentage of LEP students in the rest of a district's county as an instrument for performance. In line with other expenditure function literature 
(Duncombe \& Yinger, 2011a, 2011b), the coefficient on the instrument is positive and statistically significant at the five percent level.

The second stage results show the expected signs on key variables in the model - the performance index, the comparable wage index, and the factors related to efficiency. Moreover, they are similar in magnitude to the estimates obtained in other expenditure function research not using district fixed effects, and more particularly to the results by Duncombe and Yinger (2011a, 2011b) for California and Missouri.

The enrollment coefficients, -0.126 and 0.005 , are not statistically/ significant but show the u-shaped relationship between cost per pupil and student/enrollment that has been found in many previous studies (Andrews, Duncombe, \& Yinger, 2002). Two factors explain why the estimated effects of enrollment are not significant, as they have been in other studies. First, our sample excludes districts with fewer than 2,000 students. Earlier studies have indicated that economies of scale are exhausted at relatively low levels of enrollment and that the relationship between enrollment and costs is relatively flat for enrollments above 2000 (Andrews, Duncombe, \& Yinger, 2002). Second, our sample size is considerably smaller than recent studies (Duncombe and Yinger 2011a, 2011b).

Calculating the effect of enrollment changes on the costs of providing education in New York State, we find that a one percent increase in enrollment decreases costs by 0.05 percent for districts with an enrollment of 2000 students and by 0.02 percent for districts with an enrollment of $30,000 .^{14}$ The effect of enrollment on spending in districts with an enrollment equal to the average of our treated districts, 13,318 students, is -0.03 percent.

As anticipated, the coefficients on the variable measuring the percentage of disadvantaged students are positive. The estimates attached to the variables measuring the

\footnotetext{
${ }^{14}$ Enrollment in treated districts ranges between 2,000 and about 30,000 students in 1999.
} 
percent of students with disabilities and receiving free lunch are statistically significant at the 0.1 and 0.01 level, respectively. A one percent growth in students with disabilities raises spending per pupil by 0.5 percent and a one percent increase in students receiving free lunch expands per pupil expenditure by 0.4 percent. The results are again comparable with the cost function results for California and Missouri (Duncombe \& Yinger, 2011a, 2011b), which are 0.2 for disability and 0.5 for free lunch.

The coefficient measuring the impact of LEP students on spending per pupil is smaller and less precisely estimated relative to the other variables capturing student needs. The size of the coefficients and the large confidence interval is likely explained by the small percentage of LEP students and the small variation in this measure in our sample of districts.

To assess the magnitude of charter school effects on the costs of providing education in traditional public schools, we plug the appropriate coefficients from Table 4 and 5 into Equations 3 and 4. We display the results for these calculations in Table 6. The cost effects based on changes in the number of students with disabilities, LEP, and receiving free lunch, evaluated at the mean per pupil spending among treated districts $(\$ 22,469)$, are $\$ 1,189$ per pupil $(5.29 \%)$, $\$ 42(-0.19)$ per pupil, and $\$ 526(2.34 \%)$ per pupil, respectively. ${ }^{15}$ Only the impact of charter schools on change in the share of students receiving free lunch has a statistically significant impact on costs. The effect of charter schools on treated districts with an average enrollment is $\$ 52(0.23 \%)$. Combining all cost effects, charter schools increase spending in traditional schools by $\$ 1,724$ per pupil (7.68\%) on average. The large standard error on the estimated cost effect is mainly driven by the imprecisely measured impact of LEP students. Thus, we recalculate the

\footnotetext{
${ }^{15}$ We calculate dollar values by multiplying the percentage change in cost with average per pupil spending in treated districts for $2014(\$ 22,469)$.
} 
overall cost impact without the LEP estimate, which results in a statistically significant impact of charter schools on per pupil expenditure of $\$ 1,767$ (7.86\%) holding performance constant.

We find similar impacts on costs breaking down the post period. Considering all cost effects together, the effect of charter schools on spending per pupil is $\$ 1,686$ (7.5\%) for one to four years and $\$ 1,584(7.05 \%)$ for five to eight after charter school entry. Again, we recalculate the overall cost effect without the imprecisely estimated LEP coefficient on spending and state the results in the last row of cost effects in Table 7. The impacts are now statistically significant and amount to $\$ 1,725(7.68 \%)$ and $\$ 1,627(7.24 \%)$.

\section{Impacts on Efficiency}

Table 7 presents the results for Equation 5 using all years in our data set and the treatment and control districts described above. We show the charter treatment effects as dollar values in Table 6. Again we instrument for performance with the average percentage of LEP students in the rest of the county. The coefficients on the instrument is positive and statistically significant at the one percent level in the first stage of the spending analysis.

The treatment effect for the model using a single post period is statistically significant and suggests a reduction in per pupil expenditures associated with charter school entry of 3.3 percent, which at the mean level of per pupil spending for the treated districts is a $\$ 741$ per pupil reduction in spending per year. The second model breaks down the post period and shows an impact of 3.6 percent for one to four years and 6.8 percent for five to eight years after charter school entry, which at the treatment group mean level of spending amounts to cost reductions of $\$ 809$ per pupil and $\$ 1,528$ per pupil, respectively. The findings indicate that charter schools increase school district efficiency and that the effect grows over time. There are several reasons potentially explaining the growth in the charter school impacts over time. One reason is that 
fixed costs could be reduced in the long run. Additionally, it may take some time to adopt changes in operations in response to charter competition and those changes could take some time to realize efficiency gains. Moreover, as the share of charter school enrollment grows over time efficiency effects are likely to increase as well.

\section{Net Impacts}

We add the cost and efficiency effects to create the net impact of charter schools on school district spending per pupil. The results of these calculations are shown in the last two rows of Table 6. For the specification using a single post period, we find that charter schools increase per pupil operating expenditures in traditional school districts by $\$ 983$ (4.38\%) holding student performance levels constant. Observing the net effect over time, charter schools increase spending necessary to reach a given level of performance by $\$ 877(3.9 \%)$ in the first four years after charter school entry and by $\$ 56(0.25 \%)$ in the later years. Recalculating net effects without the imprecisely measured impact of charter schools on the share of LEP students results in small increases in the estimates and large decreases in the standard errors. None of the net effects are statistically significant, however.

The difference in effect size between earlier and later years is mainly driven by much larger efficiency gains in later time periods when charter schools enroll more students, operate a greater number of grade levels, and when traditional public schools have had more time to respond to charter school competition. Thus, although cost increases are greater than efficiency gains the first years immediately following charter school entry, over the long run, both effects offset each other.

\section{Extension of the Analysis}


The initial results show that cost effects are smaller and efficiency gains are greater in later than earlier time periods, when charter schools serve more students and have greater enrollments (see Table 2). Based on these observations, a general argument could be made that districts that are more exposed to charter school competition are also more likely to change educational programs, making them more efficient, and close traditional schools, allowing them to decrease costs to reach a predetermined level of performance. Thus, we extend our analysis and reduce the treatment group to districts with charter school enrollments of more than 10 percent in 2014.

The results for the difference-in-differences models are presented in Table 8 and show smaller charter school effects on the share of LEP and IEP students compared to the main specification. The impacts on enrollment are, not surprisingly, much larger and so is the effect of charter schools on the share of students receiving free lunch for later time periods. Both of these effects are also statistically significant.

Combining the results from Table 8 with the cost estimates from Table 5 , we calculate the effect of charter schools on district spending for districts with larger shares of charter school enrollment in Table 9. The largest difference between districts with large and small charter school enrollments is the smaller increase in share of IEP students in districts with larger charter enrollments. Perhaps the charter school sector in areas with sufficiently large charter school enrollments is able to achieve sufficient economies of scale to effectively serve students with disabilities and thus attract a large share of these students. However, in the longer-term, districts with large shares of charter school students also see larger increases in percent eligible for freelunch than do districts with smaller charter school enrollment, which increases the effects of charter school entry on costs. On net, the long run effects of charter schools on costs is slightly 
smaller in districts with larger charter school enrollments than in those will smaller charter school enrollments.

The results in Table 10 provide evidence of greater efficiency gains for districts with larger charter enrollments compared to the initial findings, suggesting that the efficiency results presented in Table 6 are driven by districts with high charter school penetration. Particularly, impacts are greater for later time periods with an effect of -11.6 percent, implying a reduction in expenditures necessary to achieve a given level of performance of $\$ 2,746$ per pupil, evaluated at the mean of the spending per pupil in this restricted set of treatment districts. Several considerations might help to explain the large efficiency gains in these districts over the longterm. When enrollment losses are sufficiently large, districts can take measures to reduce fixed costs. For instance, the city of Buffalo, one of the districts with high charter school penetration, closed several schools during the period of our study. Although some of these closures might have been in response to long standing downward trends in enrollments that preceded charter schools, additional enrollment losses resulting from charter school entry might have expedited school closure decisions. Also, it might be that districts with larger enrollment losses to charter school might have more incentive to make operational changes to either help retain students, cut costs, or both.

Considering only districts with large levels of charter school enrollment, the net of cost and efficiency impacts is always negative amounting to $-\$ 185(0.78 \%)$ for specifications using a single post period, of $-\$ 465(1.96 \%)$ for earlier, and $-1,423(6.01 \%)$ for later years after charter opening. Excluding the LEP cost effects from the calculations, the net effect is statistically significant in the later time periods. 
In sum, relative to the main results, districts with large charter school enrollments experience smaller increases in costs and greater gains in efficiency, leading to reductions in spending over the entire time period after charter school entry and particularly in later years. However, one caveat on these findings is important to mention. The districts with the greatest charter school penetration include Buffalo and Rochester, which are by far the two largest districts in the sample and have several unique features. Thus, these districts might differ from the comparison group districts in ways that create bias in our difference-in-differences estimates, Since, Buffalo and Rochester disproportionately influences the effect estimates when the sample of treated districts is limited to districts with large amounts of charter school students, we might worry that the estimated effects for these smaller group of treated districts have larger amounts of bias than our primary effect estimates.

\section{Conclusions}

Our conceptual model, based on the cost function approach, suggests that charter schools can influence the amount of spending used to achieve student outcomes in traditional school districts by changing the cost and efficiency of educating students. Costs are altered if charter schools change the composition and number of students in traditional school districts. Efficiency can increase if traditional schools react to charter competition by improving services or by reallocating resources from less to more productive uses. Decreases in efficiency can be a result of unforeseen reductions in enrollment leading to underutilization of administrators and teachers or increased spending for new programs that do not lead to increases in students' performance.

The empirical analysis shows that charter schools in New York State have increased the cost of providing education in traditional school districts mainly by increasing the share of students with disabilities and receiving free lunch in district schools. Additionally, we provide 
evidence that charter schools in New York State are associated with increased district efficiency. Comparing cost and efficiency impacts, cost increases are larger than efficiency gains on average particularly right after charter entry. In later time periods, however, both effects set each other off. School districts with large charter school enrollments experience smaller effects on costs and greater impacts on efficiency leading to spending decreases that grow over time.

The findings have important implications for policy makers and the public finance literature. First, we provide additional evidence that charter schools impact enrollment and student composition in traditional schools. However, most districts with charter school enrollments have enrollments in the range where economies of seale are largely exhausted and the relationship between costs and enrollment is relative flat. Thus, only effects on student composition, and particularly in the percent free-lunch eligible and the percent disabled, influence the cost of providing education. In so far as studies in other states and district have also found that charter schools influence the share of low-income and special education students served by traditional public schools, these findings have more general implications. Second, our study establishes, theoretically and empirically, that charter schools can influence the cost and efficiency of providing education and that both of these factors have to be considered in estimating the net effect of charters on spending in traditional public schools. Our analyses provide a framework for assessing effects on costs and efficiency. Third, we provide evidence that charter schools increase costs and the efficiency of school districts in New York, which set each other of on average but decrease spending in places with high charter school enrollment.

Our findings come with two caveats, however. First, education is characterized by the joint production of multiple outputs, and our estimates of the effect of charter schools on district efficiency only control for a limited set of those outputs. Thus, the increase in efficiency we 
estimate could reflect either the more efficient use of resources to educate students or reductions in spending for outcomes other than those for which we control. Second, even after controlling for the measures of student need that we include in our cost function, transfers to charter schools can leave district schools with students that have different underlying abilities to achieve educational objectives. We cannot determine whether the change in efficiency associated with charter school entry, as we measure it, is the result of improved district/programming and operations or changes in the underlying ability of its students.

Although there are limits to our approach of measuring charter school effects on districts costs and efficiency, it has the benefits of providing conceptual clarity and a framework for assessing the potentially countervailing effects of charter schools. Thus, we believe it would be useful to replicate this study for other states. More specifically, the efficiency gains presented in this study are likely to be associated with specific program features in New York State. Particularly, the application and monitoring processes New York State charter authorizers use has been ranked among the most comprehensive in the nation. Furthermore, almost all charter schools in New York State are non-profit organizations focusing on education-related missions and not profit maximization. These program features are likely to determine how charter schools influence efficiency in traditional public schools and thus our findings may only apply to states with similar charter policies. Application of our approach to districts in a broader set of states with a variety of charter school policies can help advance our understanding of charter school effects of traditional public school districts.

\section{Acknowledgements:}

We thank John Yinger for his insightful feedback and Phuong Nguyen-Hoang for sharing coding files. 


\section{References}

Abadie, A., Diamond, A., \& Hainmueller, J. (2015). Comparative politics and the synthetic control method. American Journal of Political Science, 59(2), 495-510.

Abdulkadiroglu, A., Angrist, J., Cohodes, S., Dynarski, S., Fullerton, J., Kane, T., \& Pathak, P. (2009). Informing the debate: Comparing Boston's charter, pilot and traditional schools. https://www.air.org/sites/default/files/downloads/report/InformingTheDebate_Final_FUll_Report_0.pdf Accessed 13 July 2018

Andrews, M., Duncombe, W., \& Yinger, J. (2002). Revisiting economies of size in American education: are we any closer to a consensus?. Economics of education review, 21(3), 245-262.

Angrist, J. D., \& Pischke, J.-S. (2009). Mostly harmless econometrics: An empiricist's companion. Princeton: Princeton University Press.

Arsen, D., Plank, D., \& Sykes, G. (1999). School Choice Policies in Michigan: The Rules Matter. For full text: http://edtech. connect. msu. edu/choice/conference/default. asp Accessed 13 July 2018

Arsen, D., \& Ni, Y. (2012). The effects of charter school competition on school district resource allocation. Educational Administration Quarterly, 48(1), 3-38.

Bettinger, E. P. (2005). The effect of charter schools on charter students and public schools. Economics of Education Review, 24(2), 133-147.

Bifulco, R., \& Buerger, C. (2015). The influence of finance and accountability policies on location of New York state charter schools. journal of education finance, 40(3), 193-221.

Bifulco, R., \& Reback, R. (2014). Fiscal Impacts of Charter Schools: Lessons from New York. Education Finance and Policy, 9(1), 86-107.

Booker, K., Gilpatric, S. M., Gronberg, T., \& Jansen, D. (2008). The effect of charter schools on traditional public school students in Texas: Are children who stay behind left behind?. Journal of Urban Economics, 64(1), 123145.

Card, D., \& Krueger, A. B. (1994). Time-series minimum-wage studies: a meta-analysis. The American Economic Review, 85(2), 238-243.

Carnoy, M., Jacobsen, R., Mishel, L. R., \& Rothstein, R. (2005). The charter school dust-up: Examining the evidence on enrollment and achievement. Washington, DC: Economic Policy Institute.

Cobb, C. D., \& Glass, G. V. (1999). Ethnic segregation in Arizona charter schools. education policy analysis archives, 7(1).

Cordes, S. A. (2017). In pursuit of the common good: The spillover effects of charter schools on public school students in New York City. Education Finance and Policy, 12 (1)1-49.

Downes, T. (2004). What is adequate? Operationalizing the concept of adequacy for New York. In: Symposium Paper for New York Education Finance Research Symposium. Albany, NY: Education Finance Research Consortium.

Downes, T. A., \& Stiefel, L. (2008). Measuring equity and adequacy in school finance. In E. Fiske \& H. F. Ladd (Eds.), Handbook of education finance and policy. pp 222-237. Mahwah, NJ: Erlbaum.

Downes, T. A., \& Pogue, T. F. (1994). Adjusting school aid formulas for the higher cost of educating disadvantaged students. National Tax Journal, 89-110.

Duncombe, W., \& Yinger, J. (1998). School finance reform: aid formulas and equity objectives. National Tax Journal, 51, 239-262.

Duncombe, W., \& Yinger, J. (2005). How much more does a disadvantaged student cost? Economics of Education Review, 24(5), 513-532.

Duncombe, W., Nguyen-Hoang, P. \& Yinger, J. (2015). Measurement of cost differentials. In: Ladd, H. \& Goertz, M. Handbook of research in education finance and policy. Ladd, Helen F., and Margaret E. Goertz, eds. Handbook of research in education finance and policy. Routledge, 238-256.

Duncombe, W., \& Yinger, J. (2011a). Making do: state constraints and local responses in California's education finance system. International Tax and Public Finance, 18(3), 337-368.

Duncombe, W., \& Yinger, J. (2011b). Are education cost functions ready for prime time? An examination of their validity and reliability. Peabody Journal of Education, 86(1), 28-57.

Eom, T. H., Duncombe, W., Nguyen-Hoang, P., \& Yinger, J. (2014). The unintended consequences of property tax relief: New York's STAR program. Education Finance and Policy. 
Epple, D., Romano, R., \& Zimmer, R. (2016). Charter schools: A survey of research on their characteristics and effectiveness. In Handbook of the Economics of Education (Vol. 5, pp. 139-208). Elsevier.

Finnigan, K., Adelman, N., Anderson, L., Cotton, L., Donnelly, M. B., \& Price, T. (2004). Evaluation of the Public Charter Schools Program: Final Report. PPSS-2004-08. US Department of Education.

Fiske, E., \& H. Ladd, (2000). "When Schools Compete: A Cautionary Tale.” Washington, D.C.: Brookings Institution.

Gill, B. (2016). The effect of charter schools on students in traditional public schools: A review of the evidence. Education Next, November, 11.

Gronberg, T. J., Jansen, D. W., \& Taylor, L. L. (2012). The relative efficiency of charter schools: A cost frontier approach. Economics of Education Review, 31(2), 302-317.

Hoxby, C.M., (2000). Does competition among public schools benefit students and taxpayers? American Economic Review 1, 209-238.c

Hoxby, C.M., (2003a). School choice and school competition: Evidence from the United States. Swedish Economic Policy Review 10, 11-67.

Hoxby, C.M., (2003b). School choice and school productivity (or, Could school choice be the tide that lifts all boats?). In: Hoxby, C.M. (Ed.), The Economics of School Choice. Univ. of Chicago Press, Chicago.

Hoxby, C. M., Murarka S., and Kang, J.. (2009). "How New York City’s charter schools affect achievement." Cambridge, MA: New York City Charter Schools Evaluation Project: 1-85.

Hull, J. (2010). Cutting to the bone: How the economic crisis affects schools. Center for Public Education. Retrieved from http://www. centerforpubliceducation. org/Main-Menu/Publiceducation/Cutting-to-the-bone-At-aglance/Cutting-to-the-bone-How-the-economiccrisis-affects-schools. html. Accessed 13 July 2018

Imazeki, J. (2008). Assessing the costs of adequacy in California public schools: A cost function approach. Education Finance and Policy, 3(1), 90-108.

Imazeki, J., \& Reschovsky, A. (2003). Financing adequate education in rural settings. Journal of Education Finance, 29(2), 137-156.

Imazeki, J., \& Reschovsky, A. (2004). Is No Child Left Behind an un (or under) funded federal mandate? Evidence from Texas. National Tax Journal, 571-588.

Imazeki, J., \& Reschovsky, A. (2006). Does No Child Left Behind place a fiscal burden on states? Evidence from Texas. Education Finance and Policy. 1(2), 217-246

Imberman, S. A. (2011). The effect of charter schools on achievement and behavior of public school students. Journal of Public Economics, 95(7), 850-863.

Jabbar, H. (2016). Selling schools: Marketing and recruitment strategies in New Orleans. Peabody Journal of Education, 91(1), 4-23.

Jackson, C. K., Wigger, C., \& Xiong, H. (2018). Do School Spending Cuts Matter? Evidence from the Great Recession(No. w24203). National Bureau of Economic Research.

Ladd, H. F., \& Singleton, J. D. (2018). The Fiscal Externalities of Charter Schools: Evidence from North Carolina. Education Finance and Policy, 1-34.

Lee V., \& Croninger, R.G.. (1994). Parental Choice of Schools and Social Stratification in Education: The Paradox of Detroit. Education Evaluation and Policy Analysis, 16(4), 434-457.

Miron, G., Urschel, J. L., Mathis, W. J., \& Tornquist, E. (2010). Schools without Diversity: Education Management Organizations, Charter Schools, and the Demographic Stratification of the American School System. Education and the Public Interest Center.

Molnar, A. (1996). Charter schools: The smiling face of disinvestment. Educational Leadership, 54(2), 9-15.

Moody's 2013 Announcement: Moody's: Charter schools pose greatest credit challenge to school districts in economically weak urban areas. Global Credit Research. https://www.moodys.com/research/Moodys- Charterschools-pose-greatest-credit-challenge-to-school-districts--PR_284505 Accessed 13 July 2018

National Alliance for Public Charter Schools (NAPCS). 2017. "Measuring Up to the Model: A Tool for Comparing State Charter School Laws.” Accessed October 9. http://www.publiccharters.org/law/ViewComponent.aspx ?comp=21).

NCES, (2018). Fast Fact. Charter schools. Available at: https://nces.ed.gov/fastfacts/display.asp?id=30 Accessed 13 July 2018.

NYS Charter School Law Subsection 2854 (2b)). https://www.nysenate.gov/legislation/laws/EDN/2854 Accessed 13 July 2018.

NYS Charter School Law Subsection 2853. https://www.nysenate.gov/legislation/laws/EDN/2853 Accessed 13 July 2018. Accessed 13 July 2018.

Oehlert, G. W. (1992) A note on the delta method. American Statistician 46: 27-29. 
Ravitch, D. (2010) The Death and Life of the Great American School System: How Testing and Choice Are Undermining Education. Basic Books: New York.

Reschovsky, A., \& Imazeki, J. (2001). Achieving education adequacy through school finance reform. Journal of Education Finance, 26, 373-396.

Reschovsky, A., \& Imazeki, J. (2003). "Let No Child Be Left Behind: Determining the Cost of Improving Student Performance." Public Finance Review 31 (3): 263-290.

Rice, J. (1994). Mathematical Statistics and Data Analysis. 2nd ed. Duxbury.

Rockoff, J. E. (2010). Local response to fiscal incentives in heterogeneous communities. Journal of Urban Economics, 68(2), 138-147.

Sass, T. R. (2006). Charter schools and student achievement in Florida. Education Finance and Policy, 1(1), 91-122.

Taylor, L. L., \& Fowler Jr, W. J. (2005). A Comparable Wage Index of School District Costs (NCES 2005-862). US Department of Education. Washington, DC: National Center for Education Statistics.

Thernstrom, Abigail and Stephen Thernstrom. (2003). No Excuses: Closing the Racial Gap in Learning. New York, NY: Simon and Schuster.

Tuttle, C. C., Teh, B. R., Nichols-Barrer, I., Gill, B. P., \& Gleason, P. (2010). Student characteristics and achievement in 22 KIPP middle schools. Mathematica Policy Research, Inc.

Wells, A. S. (1993). Time to Choose: America at the Crossroads of School Choice Policy. New York: Hill and Wang.

West, A., Ingram, D., \& Hind, A. (2006). "Skimming the Cream" Admissions to Charter Schools in the United States and to Autonomous Schools in England. Educational Policy, 20(4), 615-639.

Wooldridge, J. M. (2010). Econometric analysis of cross section and panel data. MIT press.

Zimmer, R., Gill, B., Booker, K., Lavertu, S., \& Sass, T. R. (2009). Charter schools in eight states: Effects on achievement, attainment, integration, and competition. Rand Corporation: MG-869. http://www.rand.org/content/dam/rand/pubs/monographs/2009/RAND_MG869.pdf Accessed 13 July 2018. 
Table 1: Charter School Location in New York State Outside of New York City

\begin{tabular}{|c|c|c|c|c|c|c|c|}
\hline District & $\begin{array}{c}\text { First } \\
\text { Charter } \\
\text { Established }\end{array}$ & $\begin{array}{l}\text { Number of } \\
\text { Charter } \\
\text { Schools in } \\
2013 / 14\end{array}$ & $\begin{array}{c}\text { Percentage of } \\
\text { Charter Enrollment } \\
\text { in 2013/14 }\end{array}$ & $\begin{array}{c}\text { Percentage of } \\
\text { Charter Students } \\
\text { Outside District }\end{array}$ & $\begin{array}{c}\text { Percentage of } \\
\text { Student in } \\
\text { District } \\
\text { Receiving Free } \\
\text { Lunch in } 1999 \\
\end{array}$ & $\begin{array}{c}\text { Highest } \\
\text { Percentage of } \\
\text { Charter School } \\
\text { Student in } \\
\text { Adjacent District } \\
\end{array}$ & $\begin{array}{c}\text { Percentage of } \\
\text { Students } \\
\text { Receiving Free } \\
\text { Lunch in } \\
\text { Adjacent District }\end{array}$ \\
\hline Albany & $1999 / 00$ & 11 & 21.71 & 22.15 & 51.48 & 5.41 & 42.67 \\
\hline Buffalo & $2000 / 01$ & 15 & 20.05 & 4.59 & 66.47 & 24.33 & 62.02 \\
\hline East Irondequoit $^{1}$ & $2011 / 12$ & 0 & 0.01 & N/A & 12.50 & 10.34 & 70.96 \\
\hline Greece & 2013/14 & 1 & 0.01 & 97.29 & 11.95 & 10.34 & 70.96 \\
\hline Hempstead & $2000 / 01$ & 2 & 10.54 & 25.87 & 53.39 & 2.41 & 24.74 \\
\hline Ithaca & $2009 / 10$ & 1 & 1.17 & 59.33 & 19.09 & 1.61 & 19.88 \\
\hline Kenmore-Tonawanda & $2001 / 02$ & 1 & 2.53 & 88.72 & 14.89 & 20.05 & 66.47 \\
\hline Lackawanna & $2001 / 02$ & 1 & 24.3 & 42.24 & 62.02 & 20.05 & 66.47 \\
\hline Mohonasen $^{2}$ & $2005 / 06$ & 0 & 0 & N/A & N/A & 21.71 & 51.48 \\
\hline Mount Vernon & $2011 / 12$ & 1 & 3.1 & 1.25 & 42.45 & 2.03 & 62.12 \\
\hline Newburgh & $2013 / 14$ & 1 & 0.48 & 8.47 & 43.16 & 0.01 & 4.58 \\
\hline Niagara Wheatfield & $2006 / 07$ & 1 & 0.24 & 97.48 & 14.21 & 5.23 & 42.70 \\
\hline Riverhead & $2000 / 01$ & 1 & 2.6 & 53.2 & 25.81 & 0.7 & 0.00 \\
\hline Rochester & $2001 / 02$ & 9 & 10.34 & 3.49 & 70.96 & 0.45 & 3.04 \\
\hline Roosevelt & $2000 / 01$ & 1 & 8.82 & 55.43 & 53.06 & 2.44 & 24.74 \\
\hline Schenectady ${ }^{3}$ & $2000 / 01$ & 0 & 1.7 & N/A & 49.27 & 0.01 & 7.98 \\
\hline Syracuse & $2000 / 01$ & 2 & 6.05 & 6.36 & 56.20 & 0.01 & 20.78 \\
\hline Troy & $2001 / 02$ & 2 & 18.68 & 12.91 & 39.39 & 5.4 & 12.45 \\
\hline Utica & $2013 / 14$ & 1 & 1.76 & 4.47 & 59.57 & 0.19 & 21.13 \\
\hline Yonkers & $2005 / 06$ & 1 & 2.03 & 3.72 & 62.12 & 3.1 & 42.45 \\
\hline
\end{tabular}

Sources: Basic Educational Data System (BEDS) and SUNY charter school institute

Charter school closed in 2012/13

${ }^{2}$ Charter school closed in 2008/09

${ }^{3}$ Charter school closed in 2004/05

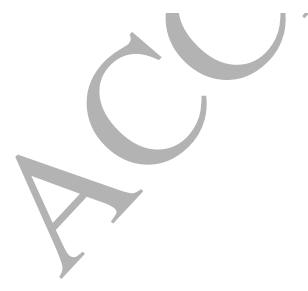


Table 2: Charter School Enrollment

\begin{tabular}{|c|c|c|c|c|}
\hline \multirow[b]{2}{*}{ District } & \multicolumn{2}{|c|}{ First Year } & \multicolumn{2}{|c|}{ Last Year } \\
\hline & K-8 & $9-12$ & K-8 & $9-12$ \\
\hline Albany & 381 & 86 & 1,437 & 863 \\
\hline Buffalo & 96 & 0 & 4,350 & 3,167 \\
\hline East Irondequoit $^{1}$ & 13 & 0 & 13 & 0 \\
\hline Greece $^{2}$ & 24 & 14 & 24 & 14 \\
\hline Hempstead & 15 & 0 & 759 & 21 \\
\hline Ithaca & 0 & 52 & 0 & 61 \\
\hline Kenmore-Tonawanda & 29 & 0 & 127 & 94 \\
\hline Lackawanna & 51 & 10 & 367 & 245 \\
\hline Mohonasen $^{3}$ & 14 & 0 & 12 & 0 \\
\hline Mount Vernon & 12 & 0 & 169 & 83 \\
\hline Newburgh $^{2}$ & 0 & 54 & 0 & 54 \\
\hline Niagara Wheatfield & 5 & 0 & 10 & 0 \\
\hline Riverhead & 190 & 0 & 140 & 0 \\
\hline Rochester & 301 & 0 & 1,904 & 1,39 \\
\hline Roosevelt & 53 & 0 & 307 & 0 \\
\hline Schenectady ${ }^{4}$ & 22 & 0 & 67 & \\
\hline Syracuse & 349 & 0 & 826 & 470 \\
\hline Troy & 21 & 0 & 646 & 177 \\
\hline Utica & 43 & 128 & & 128 \\
\hline Yonkers & 171 & 0 & 426 & 88 \\
\hline
\end{tabular}

Notes: The table shows charter school enrollment broken down into grades K-8 and 9-12 for the first year a charter school was open in the district and the last year we observe charter school enrollment in the district.

Sources: same as Table 1

${ }^{1}$ Charter school operated only one year

${ }^{2}$ Only one year is observed in the data

${ }^{3}$ Charter school operated only four years

${ }^{4}$ Charter school operated only five years 
Table 3: Summary Statistics for Treated and Control Districts

\begin{tabular}{|c|c|c|c|c|c|}
\hline & \multicolumn{2}{|c|}{ Treated Districts } & \multicolumn{2}{|c|}{ Control Districts } & \multirow[b]{2}{*}{$\begin{array}{c}\text { Mean } \\
\text { Difference }\end{array}$} \\
\hline & Mean & $\begin{array}{c}\text { Standard } \\
\text { Deviation }\end{array}$ & Mean & $\begin{array}{l}\text { Standard } \\
\text { Deviation }\end{array}$ & \\
\hline District Count & \multicolumn{2}{|c|}{14} & \multicolumn{2}{|c|}{14} & \\
\hline Operating expenditures ${ }^{1}$ & 16,384 & 1,667 & 16,499 & 3,423 & -114 \\
\hline $\begin{array}{l}\text { Performance Index }{ }^{1} \\
\text { (Mean of \% proficient, } \% \text { earning } \\
\text { diploma, and \% non-dropout) }\end{array}$ & 46.02 & 6.51 & 49.52 & 9.12 & -3.5 \\
\hline \multicolumn{6}{|l|}{ Cost Related Variables } \\
\hline Comparable wage index ${ }^{2}$ & 1.02 & 0.12 & 1.00 & 0.13 & 0.02 \\
\hline Enrollment $^{1}$ & 13,318 & 13,758 & 5,269 & 3,796 & $8,048^{*}$ \\
\hline $\begin{array}{l}\text { Percent of students with } \\
\text { disabilities }{ }^{1}\end{array}$ & 14.37 & 5.12 & 13.75 & 2.78 & 0.62 \\
\hline Percent LEP students ${ }^{1}$ & 5.98 & 5.08 & 7.76 & 5.8 & -1.78 \\
\hline Percent free lunch ${ }^{1}$ & 55.06 & 8.78 & 52.16 & 11.29 & 2.9 \\
\hline \multicolumn{6}{|l|}{ Efficiency Variable } \\
\hline Local tax share ${ }^{1,3,4}$ & 0.54 & 0.22 & 0.50 & 0.19 & 0.04 \\
\hline Share of state aid ${ }^{1}$ & .05 & 0.1 & 0.05 & 0.1 & 0 \\
\hline Income per pupil ${ }^{1}$ & 100,197 & 26,151 & 97,647 & 31,937 & 2,549 \\
\hline Percent college graduates ${ }^{3,4}$ & 19.46 & 5.78 & 16.40 & 4.23 & 3.06 \\
\hline Percent youth (age $5-17$ ) & 28.22 & 2.19 & 29.08 & 3.85 & -0.86 \\
\hline $\begin{array}{l}\text { Instrumental Variable } \\
\text { Average percent of LEP students } \\
\text { in the county (excluding focal } \\
\text { district) }\end{array}$ & 2.27 & 0.34 & 2.13 & 0.56 & 0.14 \\
\hline
\end{tabular}

Notes: Summary measurements are for the year 1998/99, the only year in the data set without charter schools for all treated districts. All monetary values are adjusted for inflation and displayed in 2014 dollars. Differences in means are tested using a t-test: $* * * \mathrm{p}<0.01 ; * * \mathrm{p}<0.05 ; * \mathrm{p}<0.1$.

Sources: ${ }^{1}$ From New York State Education Department.

${ }^{2}$ From National Center for Education Statistics.

${ }^{3}$ From American Community Survey

${ }^{4}$ From U.S. Census (the annual values for inter-census years between 1999 and 2009 were interpolated by using the linear growth rate between 1999 and 2009).

${ }^{5}$ From U.S. Census, Count Business Patterns 
Table 4: Effects of Charter School Entry on Student Composition and Enrollment

\begin{tabular}{|c|c|c|c|c|c|c|c|c|}
\hline & \multicolumn{2}{|c|}{ Percentage Free Lunch } & \multicolumn{2}{|c|}{ Percentage LEP } & \multicolumn{2}{|c|}{ Percentage IEP } & \multicolumn{2}{|c|}{ Log Enrollment } \\
\hline & (1) & (2) & (3) & (4) & (5) & $(6)$ & (7) & (8) \\
\hline \multicolumn{9}{|l|}{ Treatment } \\
\hline Treatment $\times$ Post & $\begin{array}{l}2.956^{*} \\
(1.540)\end{array}$ & & $\begin{array}{c}-2.821 * * \\
(1.057)\end{array}$ & & $\begin{array}{l}1.608 * \\
(0.937)\end{array}$ & & $\begin{array}{c}-0.074 * * * \\
(0.025)\end{array}$ & \\
\hline $\begin{array}{l}\text { Treatment } \times \text { Years } \\
1,2,3 \text {, and } 4 \text { Post }\end{array}$ & & $\begin{array}{c}3.137 \\
(2.705)\end{array}$ & & $\begin{array}{c}-2.569 * * * \\
(0.762)\end{array}$ & & 1.51 & & $\begin{array}{c}-0.062 * * * \\
(0.021)\end{array}$ \\
\hline $\begin{array}{l}\text { Treatment } \times \text { Years } \\
5,6,7 \text {, and } 8 \text { Post }\end{array}$ & & $\begin{array}{c}2.629 \\
(1.847)\end{array}$ & & $\begin{array}{l}-2.856^{*} \\
(1.565)\end{array}$ & & (1.573) & & $\begin{array}{c}-0.089^{* *} \\
(0.035)\end{array}$ \\
\hline \multicolumn{9}{|l|}{ Other } \\
\hline Constant & $\begin{array}{l}53.071 * * * \\
\quad(1.05)\end{array}$ & $\begin{array}{l}53.001 * * * \\
\quad(1.06)\end{array}$ & $\begin{array}{c}6.433 * * * \\
(0.729)\end{array}$ & $\begin{array}{c}6.482 * * * \\
(0.72)\end{array}$ & $\begin{array}{l}13.891 * * * \\
(0.701)\end{array}$ & $\begin{array}{l}13.871 * * * \\
\quad(0.67)\end{array}$ & $\begin{array}{l}8.6752 * * * \\
\quad(0.02)\end{array}$ & $\begin{array}{c}8.671 * * * \\
(0.02)\end{array}$ \\
\hline District fixed effects & Yes & Yes & Yes & Yes & Yes & Yes & Yes & Yes \\
\hline Year fixed effects & Yes & Yes & Yes & Yes & Yes & Yes & Yes & Yes \\
\hline Observations & 448 & 448 & 448 & 448 & 448 & 448 & 448 & 448 \\
\hline $\begin{array}{l}\text { Number of census } \\
\text { R-squared }\end{array}$ & $\begin{array}{c}28 \\
0.363\end{array}$ & $\begin{array}{c}28 \\
0.368\end{array}$ & $\begin{array}{c}28 \\
0.380\end{array}$ & $\begin{array}{c}28 \\
0.394\end{array}$ & $\begin{array}{c}28 \\
0.383\end{array}$ & $\begin{array}{c}28 \\
0.412\end{array}$ & $\begin{array}{c}28 \\
0.381\end{array}$ & $\begin{array}{c}28 \\
0.412\end{array}$ \\
\hline
\end{tabular}

Notes: Robust standard errors are clustered at the district level: *** $\mathrm{p}<0.01 ; * * \mathrm{p}<0.05 ; * \mathrm{p}<0.1$

Sources: All sources are the same as in Table 3. 
Table 5: Estimates of Cost Functions

Log of per pupil operating expenditure excl. charter tuition

\begin{tabular}{|c|c|}
\hline Performance Index & $\begin{array}{c}0.52143 \\
(0.54087)\end{array}$ \\
\hline Comparable wage index & $\begin{array}{c}0.96769^{* * * *} \\
(0.10085)\end{array}$ \\
\hline Enrollment $^{\mathrm{a}}$ & $\begin{array}{l}-0.12568 \\
(0.23242)\end{array}$ \\
\hline Enrollment squared $^{\mathrm{a}}$ & $\begin{array}{c}0.00507 \\
(0.01331)\end{array}$ \\
\hline Percent of students with disabilities & $\begin{array}{l}0.00473 * \\
(0.00270)\end{array}$ \\
\hline Percent LEP students & $\begin{array}{c}0.00004 \\
(0.00470)\end{array}$ \\
\hline Percent free lunch & $\begin{array}{c}0.00436^{* * * *} \\
(0.00101)\end{array}$ \\
\hline Local tax share ${ }^{a}$ & $\begin{array}{l}-0.10613 * \\
(0.05519)\end{array}$ \\
\hline State aid term ${ }^{\mathrm{a}}$ & $\begin{array}{c}0.03337 \\
(0.03296)\end{array}$ \\
\hline Income per pupil ${ }^{\mathrm{a}}$ & $\begin{array}{c}0.19091 * * * \\
(0.06967)\end{array}$ \\
\hline Percent college graduates & $0.07331 * *$ \\
\hline Percent youth (age 5 - 17) & $\begin{array}{l}0.01382 \\
(0.09534)\end{array}$ \\
\hline $\begin{array}{l}\text { Observations } \\
\text { R-squared }\end{array}$ & $\begin{array}{c}287 \\
0.6759 \\
\end{array}$ \\
\hline
\end{tabular}

Notes: Regression is estimated instrumenting for performance. Coefficients have four digits behind the decimal point. Robust standard errors are clustered at the district level: $* * * \mathrm{p}<0.01 ; * * \mathrm{p}<0.05$; $* \mathrm{p}<0.1$.

${ }^{a}$ Variable is log transformed

Sources: All variables measured in school year 1998/99, the only year in the data set without charter schools for all treated districts. All sources are the same as in Table 3. 
Table 6: Effects on Cost and Efficiency in Dollar Values

\begin{tabular}{|c|c|c|c|}
\hline & $\begin{array}{c}\text { One post period } \\
\text { (1) }\end{array}$ & $\begin{array}{c}1 \text { to } 4 \text { years } \\
\text { (2) }\end{array}$ & $\begin{array}{c}5 \text { to } 8 \text { years } \\
\text { (3) }\end{array}$ \\
\hline \multicolumn{4}{|l|}{ Cost Effects } \\
\hline Free Lunch & $\begin{array}{c}\$ 526 * * \\
(221)\end{array}$ & $\begin{array}{l}\$ 558^{*} \\
(308)\end{array}$ & $\begin{array}{l}\$ 468 \\
(243)\end{array}$ \\
\hline LEP & $\begin{array}{c}-\$ 42 \\
(4,983)\end{array}$ & $\begin{array}{c}-\$ 39 \\
(4,539)\end{array}$ & $\begin{array}{l}-\$ 43 \\
(243)\end{array}$ \\
\hline IEP & $\begin{array}{c}\$ 1,189 \\
(877)\end{array}$ & $\begin{array}{c}\$ 1,123 \\
(823)\end{array}$ & $\begin{array}{c}\$ 1,098 \\
(901)\end{array}$ \\
\hline Enrollment (avg.) & $\begin{array}{l}\$ 52 \\
(41)\end{array}$ & $\begin{array}{l}\$ 43 \\
(35)\end{array}$ & $\begin{array}{l}\$ 62 \\
(50)\end{array}$ \\
\hline Sum & $\begin{array}{l}\$ 1,724 \\
(4,871)\end{array}$ & $\begin{array}{l}\$ 1,686 \\
(4,457)\end{array}$ & $\begin{array}{l}\$ 1,584 \\
(4,946)\end{array}$ \\
\hline Sum (excl. IEP) & $\begin{array}{c}\$ 1,767 * * \\
(885)\end{array}$ & $\begin{array}{c}1,725 * * \\
(836)\end{array}$ & \\
\hline Efficiency & $\begin{array}{c}\$ 741 * * \\
(337)\end{array}$ & $\begin{array}{c}\$ 809 * * * \\
(247)\end{array}$ & (337) \\
\hline Net & $\begin{array}{c}\$ 983 \\
(4,898)\end{array}$ & $\$ 8$ & $\begin{array}{c}\$ 56 \\
(4,947)\end{array}$ \\
\hline Net (excl. IEP) & $\begin{array}{c}\$ 1,026 \\
(948)\end{array}$ & $(893)$ & $\begin{array}{c}\$ 99 \\
(998) \\
\end{array}$ \\
\hline
\end{tabular}

Notes: Cost effects are calculated using Equations 3 and 4. Average enrollment is 13,318 students. Efficiency effects are taken from Table 6. The financial numbers for Models 1 to 3 are calculated using the average per pupil operating expenditure for treaded districts in 2014 $(\$ 22,469)$. The delta method is used to calculate standard errors, which are stated in parentheses. Standard errors are: $* * * \mathrm{p}<0.01 ; * * \mathrm{p}<0.05 ; * \mathrm{p}<0.1$ 
Table 7: Efficiency Estimates

Log of per pupil operating expenditure excl. charter tuition

(1)

$-0.033 * *$

(0.015)

Treatment X Years 1, 2, 3, and 4

Post

$-0.036 * * *$

(0.011)

Treatment X Years 5, 6, 7, and 8

Post

$-0.068 * * *$

(0.015)

\section{Controls}

District fixed effects

Year fixed effects

Observations

R-squared

\# Districts

Notes: Models $1998 / 99$ to $2013 / 14$. Regression is estimated instrumenting for performance. Robust standard errors are clustered at the district level: *** $\mathrm{p}<0.01 ; * * \mathrm{p}<0.05 ; * \mathrm{p}<0$. Sources: All sources are the same as in Table 3. 
Table 8: Effects on Student Composition and Enrollment Extended Analysis

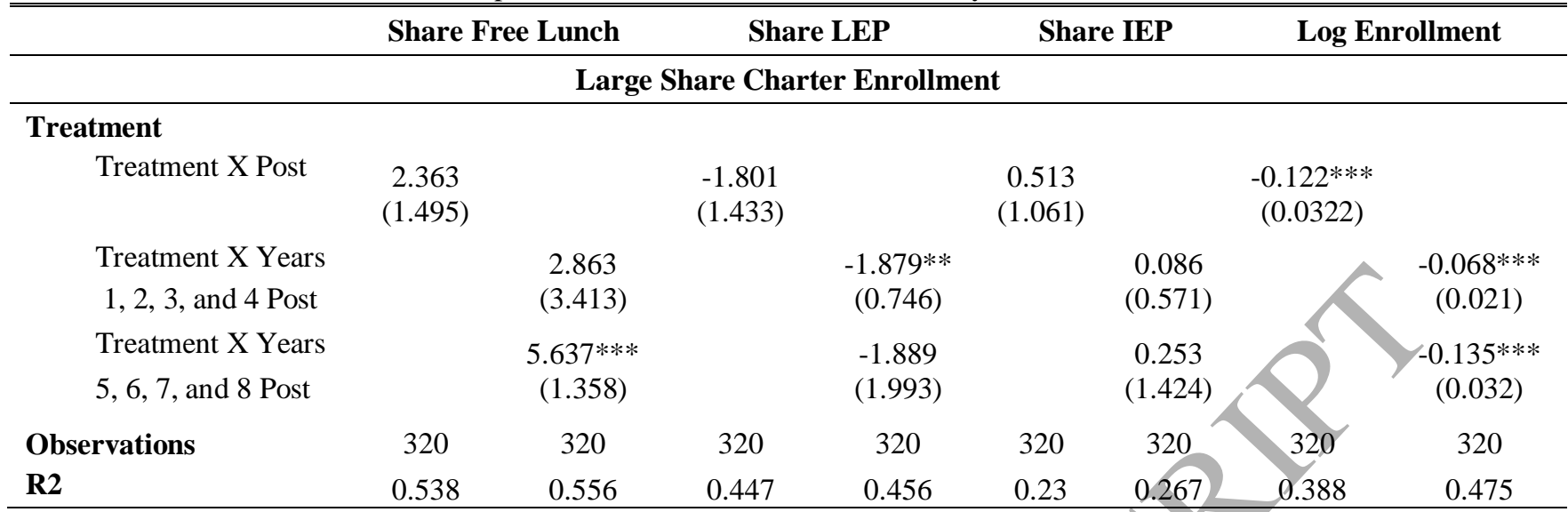

Notes: Regressions include year and districts fixed effects. Constants are not displayed. Robust standard errors in parenthesis: *** $\mathrm{p}<0.01$; ** $\mathrm{p}<0.05$; * $\mathrm{p}<0.1$

Sources: All sources are the same as in Table 3. 
Table 9: Effects on Cost and Efficiency in Dollar Values for Extended Analysis

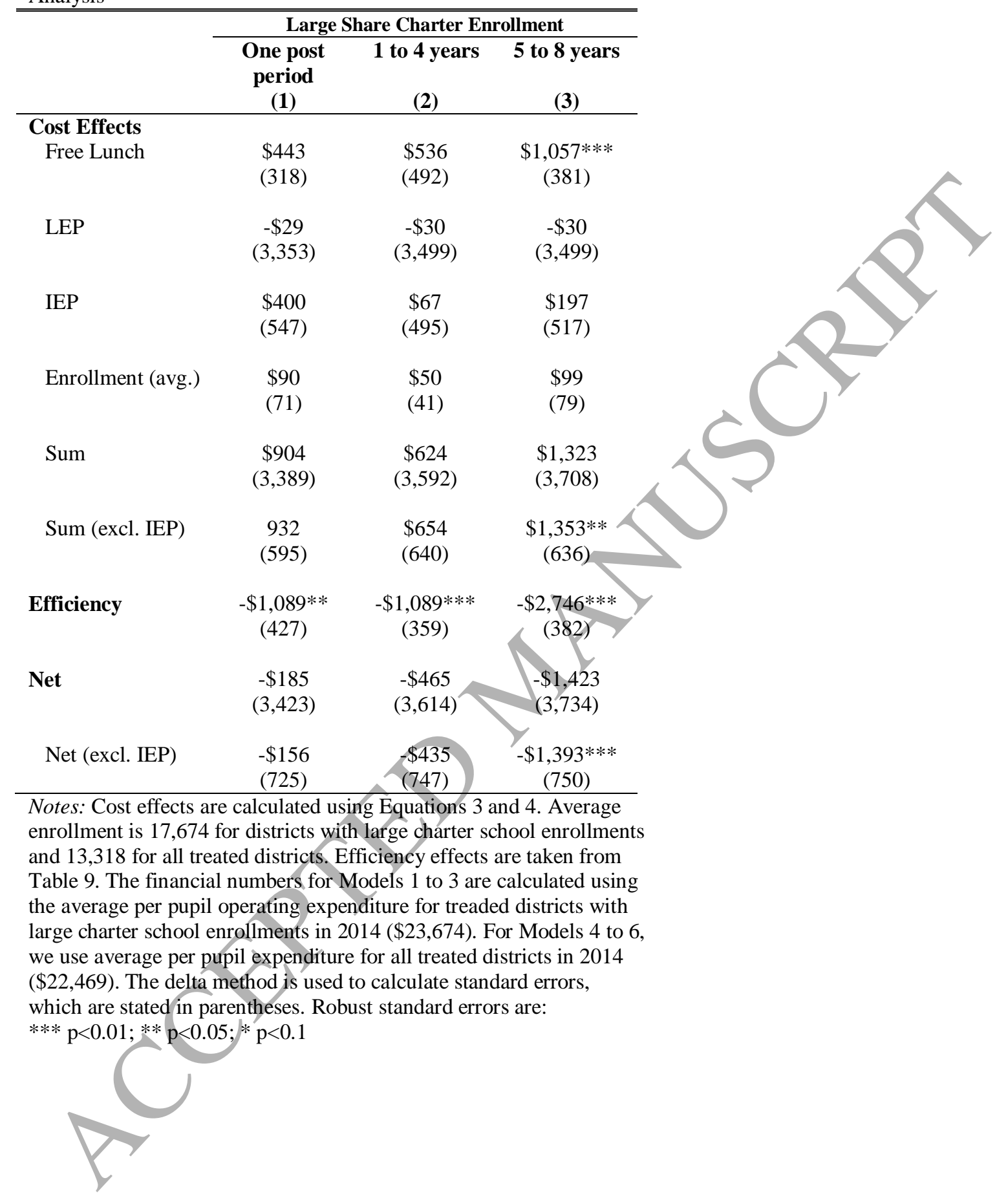


Table 10: Efficiency Estimates for Extended Analysis

Log of per pupil operating expenditure excl. charter tuition

Large Share Charter Enrollment

(1)

(2)

\begin{tabular}{cc}
\hline Treatment X Post & $-0.046^{* *}$ \\
& $(0.019)$
\end{tabular}

Treatment X Years 1, 2, 3, and 4 Post $-0.046 * * *$

Treatment X Years 5, 6, 7, and 8 Post

$-0.116^{* * *}$

(0.017)

Observations

320

R-squared

20

\# Districts

20

Notes: Models include the same variables as in Table 5. Variables are measured from 1998/99 to 2013/14. Regression is estimated instrumenting for performance. Robust standard errors are clustered at the district level: $* * * \mathrm{p}<0.01 ; * * \mathrm{p}<0.05 ; * \mathrm{p}<0.1^{\mathrm{a}}$ Variable is $\log$ transformed. Sources: All sources are the same as in Table 3. 